\title{
The influence of a single species on the space use of mixed-species flocks in Amazonian Peru
}

\author{
Sean M. Williams ${ }^{1,2,3^{*}}$ (D) and Catherine A. Lindell ${ }^{1,2,4}$
}

\begin{abstract}
Background: The drivers of space use patterns of multi-species groups have been poorly studied, although mixedspecies avian flocks are common throughout the world. In a mixed-species flock, multiple species move together and maintain proximity. The different species may or may not have conflicting preferences of space use. We hypothesized that the space use patterns of the flock are driven by a single species.

Methods: We investigated the behavioral drivers of space use patterns of mixed-species flocks in Amazonian Peru by mapping 95\% fixed-kernel home ranges of three flocks, which then we divided into high-use (inner 55\% kernel utilization distribution) and low-use areas (lying outside the high-use area). We quantified the foraging and antipredator behavior of individual birds in the flocks. We tested whether foraging and anti-predator behavior of different species were different in high use and low use areas of the flock.

Results: We collected 455 spatial points and 329 foraging and anti-predator behavior observations on three flocks. The single best model for explaining the space use patterns of the flocks contained only vegetation density that surrounded Dusky-throated Antshrikes.

Conclusion: The results are consistent with the hypothesis that a single species in mixed-species flocks has a disproportionately large influence on space use patterns. The surrounding vegetation density of the Dusky-throated Antshrike was the only driver of space use patterns of flocks supported by our data. The results may apply to flocks pantropically, many of which are led by species that behave similarly to the Dusky-throated Antshrike, e.g. Asian flocks led by drongos (Dicrurus spp.).
\end{abstract}

Keywords: Anti-predation, Foraging behavior, Antbird, Thamnomanes, Myrmotherula, Rainforest, Habitat use, Multispecies group

\section{Background}

Determining where animals spend time is key for understanding their ecology and informing conservation efforts $[7,31,39,41,54]$. Animals may associate with conspecifics in groups, such as breeding pairs, herds, and colonies. The proximate drivers of associating with other individuals include mating opportunities, antipredator defense, and increased foraging efficiency. For similar reasons (barring mating opportunities), animals

\footnotetext{
* Correspondence: seanbirder@gmail.com

${ }^{1}$ Department of Integrative Biology, Michigan State University, East Lansing, MI, USA

${ }^{2}$ Program for Ecology, Evolutionary Biology, and Behavior, Michigan State University, East Lansing, MI, USA

Full list of author information is available at the end of the article
}

may associate with individuals of different species. The drivers of space use of single individuals and monospecific groups are well studied; in contrast, few studies have examined drivers of space use of mixed-species groups $[3,20,25,60,81]$, which are prevalent in avian communities [27, 30, 72].

Throughout the world, hundreds of species participate in mixed-species flocks $[8,29,55]$. A mixed-species flock is a group of individual birds that move spatially and independent of each other, although in the same direction [26]. Recent studies have focused on flock composition $[4,82]$, physical and behavioral similarities among flock participants [72-74], the stability of flocks over time [45], and the effect of urbanization on flock dynamics

(c) The Author(s). 2019 Open Access This article is distributed under the terms of the Creative Commons Attribution 4.0 International License (http://creativecommons.org/licenses/by/4.0/), which permits unrestricted use, distribution, and 
[27, 44]; few studies, however, have addressed factors that influence their space use (but see [60]).

Organisms prefer to spend time in areas rich in resources and low in predation risk [19, 23, 32, 33]. For example, Swainson's Warblers (Limnothlypis swainsonii) space use corresponded to the patchy spatial distributions of certain plants and habitat types [3]. In single-species groups, the decisions of space use are typically made by one or a few individuals rather than collectively by all individuals $[49,58$, 79]. Movements of olive baboons (Papio anubis) are initiated by a single individual when that individual moves in a highly directed manner [76]. In wintering groups of unrelated Willow Tits (Poecile montanus), adults are more likely to lead than hatch-year birds [35].

A mixed-species flock may function similarly to a single-species group in that a single species or individual may largely decide space use of the entire flock. In Amazonian mixed-species flocks, the Dusky-throated Antshrike (Thamnomanes ardesiacus; hereafter Duskythroated Antshrike) and the Long-winged Antwren (Myrmotherula longipennis; hereafter Long-winged Antwren) are nuclear species, which are species nearly always found in a flock, and almost never away from a flock [30, 53]. Some nuclear species are virtually always found in flocks, but not all flocks contain those species, e.g. Bluish-slate Antshrike (T. schistogynus) and Whiteflanked Antwren (M. axillaris). Over 50 other transient species, e.g. White-eyed Antwren (Epinecrophylla leucophthalma) and White-flanked Antwren (Myrmotherula axillaris), may associate with these flocks or not [17, $38,53,79]$. Because transient species are found in the flocks inconsistently, we did not expect transient species to have a regular influence on space use of flocks. Other flock participant roles include: leader species, which facilitate flock formation and cohesion; follower species, which follows other individuals in the flock; and sentinel species, which detect and alert the presence of predators. Some species simultaneously may play multiple roles, such as the Dusky-throated Antshrike, which is considered a nuclear, a leader, and a sentinel.

The distribution of animals can often be predicted by habitat characteristics $[6,24,68]$, which suggests that animals rely on habitat characteristics when making finescale space use decisions. For example, animals likely use vegetation density as an indicator of resource availability and predation risk, although the preferred vegetation density is highly species-specific [14, 56, 67]. Duskythroated Antshrikes scan leaves from an exposed perch for arthropods at a height of $2.6 \mathrm{~m}$ above the ground. Upon detecting prey, they sally-glean the surfaces of leaves, whereby stationary prey is removed from a leaf in flight. They return to their perch and dismantle their prey. This preference for exposed perches, i.e. sparsely vegetated areas, and sally-gleaning foraging style yield opportunities to simultaneously scan for distant ambush predators like forest-falcons [69, 80]. Dusky-throated Antshrikes likely spend time in areas with a low vegetation density because there are available prey and a low risk of predation. Transient flock species are attracted to Dusky-throated Antshrikes more strongly than to Long-winged Antwrens [83]. Therefore, the space use patterns of the flock may be driven, in large part, by the preferred habitat characteristics of the Dusky-throated Antshrikes.

We hypothesized that the foraging attack rate (a proxy for resource availability $[59,63]$ ), vigilance rate (a proxy for predation risk [13, 47];), and vegetation density surrounding the Dusky-throated Antshrikes would explain the space use of the flock. We predicted that Duskythroated Antshrikes would have higher attack rates, lower vigilance rates, and forage in sparser vegetation density in high use areas of the flock compared to low-use areas. Conversely, we predicted that the attack rates, vigilance rates, and vegetation density of the other nuclear, less attractant species, i.e. Long-winged Antwren, Bluish-slate Antshrike, and White-flanked Antwren, would not be different in high and low use areas of the flock. If the data support these predictions, it suggests that high use areas of the flock are optimal for the Dusky-throated Antshrike rather than the other species, and that Dusky-throated Antshrike preferences drive space use of the flock.

\section{Methods \\ Study sites}

Data were collected at Los Amigos Biological Station (12.568 S, $70.100 \mathrm{~W})$ in May-Aug 2013-2014, during the dry season when breeding activity is relatively low. Los Amigos is situated among $1500 \mathrm{~km}^{2}$ of primary rainforest at $300 \mathrm{~m}$ above sea level in eastern Madre de Dios, Peru. Understory mixed-species flocks containing antshrikes and antwrens are abundant and present year-round, and are located by listening for the continuous vocalizations of flock members. Over 50 species participate in these mixed-species flocks [53]. Based on our observations from 2012 to 2015, the home ranges of the flocks are stable, and neighboring flocks have relatively little overlapping area ( $<5 \%$ of total home range size), consistent with previous work [45]. In May-Jul 2013 and May-Jun 2014, SMW color-banded 26 individuals of four species (Duskythroated Antshrike, Bluish-slate Antshrike, Long-winged Antwren, and White-flanked Antwren) from three flocks in terra firme habitat for individual recognition. Two of the flocks were adjacent to each other and their home ranges overlapped by about $50 \mathrm{~m}^{2}$. Another flock was 650 $\mathrm{m}$ away from these two flocks and did not overlap.

\section{Spatial data collection}

Data were collected on each flock 1-2 times per week. We entered each home range 5 minutes before dawn at 
a location where the flock was known to gather every morning. We followed a flock until 6 hours after dawn. We considered birds to be flocking when they were actively moving along branches and gleaning or sallying insects, and maintaining a distance of $10 \mathrm{~m}$ or less between species for five or more minutes [51, 75]. We observed birds at a distance of $1-10 \mathrm{~m}$ from the bird when birds were unobstructed by vegetation. Distance was judged based on visual calibration after practice with rangefinders and measuring tape. Every twenty minutes we took geographic coordinates of the flock using a Garmin GPSMap 78, which was accurate to 3-5 m [3]. The coordinates were taken at the position judged to be the centroid of the flock such that all or nearly all flock members were within $5 \mathrm{~m}$ of the point.

\section{Behavioral observations}

We recorded behavioral observations of antshrikes and antwrens as long as possible (min $30 \mathrm{~s}$ ) using a digital voice recorder while the birds were foraging. Flocks were followed each day, and behavioral data was collected opportunistically when birds remained in view for $30 \mathrm{~s}$ or longer. We recorded the vegetation density, the attack rate, the vigilance rate, and GPS coordinates of the position of the bird for every behavioral observation, following the focal-animal sampling method proposed by Altmann [1].

No more than one observation per hour per colorbanded individual was taken in order to reduce nonindependence of observations, following recommendations by Swihart \& Slade [78], Lair [42], and Pechacek [57]. When collecting observations on non-banded individuals, we did not use an individual of the same species more than once per hour unless we were certain it was known to be a different individual based on plumage differences due to age or sex. The flocks moved 120$180 \mathrm{~m}$ per hour, although they sometimes moved over $300 \mathrm{~m}$ per hour. The home ranges were less than $300 \mathrm{~m}$ at the widest, and so flocks could have moved to any point in the home range within an hour. Therefore, the movements over 1 hour reflect choices by the flocks to forage in preferred areas rather than an inability to reach any location within a home range [42].

The attack rate was defined as the number of capture attempts of prey per unit time. The attack rate approximates the number of insects consumed and so the attack rate increases with prey availability $[36,59,63]$. Following recommendations of Remsen \& Robinson [62], we defined an attack as the action of the bill striking or picking up an object. Vigilance rate is the proportion of time spent vigilant,which has been used as a proxy of predation risk since vigilance increases with predation risk [13, 43, 47]. Because antshrikes and antwrens forage low to the ground $(<5 \mathrm{~m})$, and forest-falcons ambush from the canopy, birds were considered vigilant when the bill was held horizontally or pointed upward $[48,65,69]$.

Immediately following an observation, we visually estimated the vegetation density within a one-meterradius sphere of the bird based on the percent of light that passed through the sphere, following recommendations of "foliage density" sampling by Remsen \& Robinson [62]. A score of $0 \%$ indicated that all light passed through the sphere because there was no vegetation.

Although we observed 32 species in the flocks, only four species were common enough to obtain a sufficient number of observations to be included in the analyses. The four species used in the analyses were: the Long-winged Antwren, the Dusky-throated Antshrike, the Whiteflanked Antwren, and the Bluish-slate Antshrike.

\section{Data analyses}

The home range of the flock was defined as the 95\% fixed-kernel home range, following recommendations of Worton [84]. A high use area was calculated using the inner 55\% area from the modeled kernel distribution, and the low use area was defined as the area lying outside the high use area, but still within the home range. Isopleths of $50-60 \%$ are typically used for defining high use area $[3,34,66]$. The $55 \%$ isopleth was chosen because it delineated hotspots of space use (pers. obs.). The home ranges, high use areas, and low use areas were calculated with the "kernelUD" and "getverticeshr" functions of the "adehabitatHR" package of the R Statistical Software, version 3.2.3 $[9,12]$. The smoothing parameters were chosen using least-squares cross-validation, following recommendations of Seaman et al. [70].

To determine whether enough locations were sampled for home range kernel density estimation, we used the "rhr" package of the R Statistical Software, version 3.2.3 [9, 71]. Home range asymptotes were reached for each flock after 50 locations, which is a typical number of sampling locations to reach an asymptote $[2,70]$.

We used a generalized mixed model with a binomial distribution and logit link function to investigate whether attack rate, vigilance rate, and vegetation density surrounding the bird, of each of the four species distinguished areas of high (within the $55 \%$ isopleths of the home ranges) or low (between the 55 and 95\% isopleths of the home ranges) space use by the flocks. Flock and individual were considered random effects. We built a set of candidate models to investigate the effects of attack rate, vigilance rate, and vegetation density of all four focal species on the likelihood of presence of the flock (Table 4 in Appendix). Models included all combinations of attack rate, vigilance rate, and vegetation density of the four focal species (full model), the Dusky-throated Antshrike, the three non-Dusky-throated Antshrike focal species, and a set of models whereby the data of each of the three behavioral variables were not 
coded by species. We calculated an Akaike Information Criterion (AIC), $\triangle \mathrm{AIC}\left(\mathrm{AIC}_{i}-\mathrm{AIC}_{\text {min }}\right.$ ), and normalized model likelihoods $(w)$ for each model.

The best selected model was at least 2 AIC units lower than the model with the next lowest AIC score [11]. The directions and strengths of the effects of the predictor variables on the response variable were estimated with 95\% confidence intervals. A strong effect was defined as an interval that did not include zero, an intermediate effect included zero but was not centered on zero, and a noneffect was centered on zero $[10,18]$. The "glmer" function of the "lme4" package was used for modeling [5] and the "AICtab" function of the "bbmle" package was used for the model selection [9]. All analyses were performed with the R Statistical Software, version 3.2.3 [9, 61]. The estimates are reported \pm standard errors.

\section{Results}

We collected, 134, 173, and 148 locations for each of the three flocks. Home range sizes were 6.74, 6.34, and 5.08 ha, and high use areas were 2.04, 2.46, and 1.79 ha, respectively (A, B, and C of Fig. 1). We collected 329 behavioral observations from 26 individuals of four species (Table 1). 288 of the observations (83\%) came from banded individuals. A total of 32 species joined the flocks (Table 5 in Appendix).

Only one model was substantially supported $(<2 \Delta$ AIC), and this model $(w=0.53)$ contained vegetation density of the Dusky-throated Antshrike as the only fixed-effect predictor (Table 2). The 95\% confidence interval of the effect of vegetation density of the Dusky-throated Antshrike on the space use of the flock was $(-8.53,-2.07)$. The $\triangle$ AIC of the next two most likely models both were 2.0 and included the vegetation density of the Dusky-throated Antshrike and either the attack rate $(-30.36,34.58)$ or vigilance rate $(-14.26,15.69)$ of the Dusky-throated Antshrike. The mean vegetation density of the Duskythroated Antshrike was lower in the high use areas of the flock than low use areas (Table 3). None of the models with $\triangle \mathrm{AIC}<2$ contained individual or flock effects.

\section{Discussion}

The results supported our prediction that the surrounding vegetation density of the Dusky-throated Antshrike, explained space use patterns of mixed-species flocks. None of the other models containing variables for the other species were supported. The areas in which the flocks spent the most time could be predicted by vegetation density of Dusky-throated Antshrike foraging locations.

Dusky-throated Antshrikes forage by perching still in areas with low vegetation density and scanning distant vegetation $[69,80]$. They search for food hyperopically, which likely facilitates the detection of aerial predators, i.e. forest-falcons, which commonly barrage flocks. Dusky-

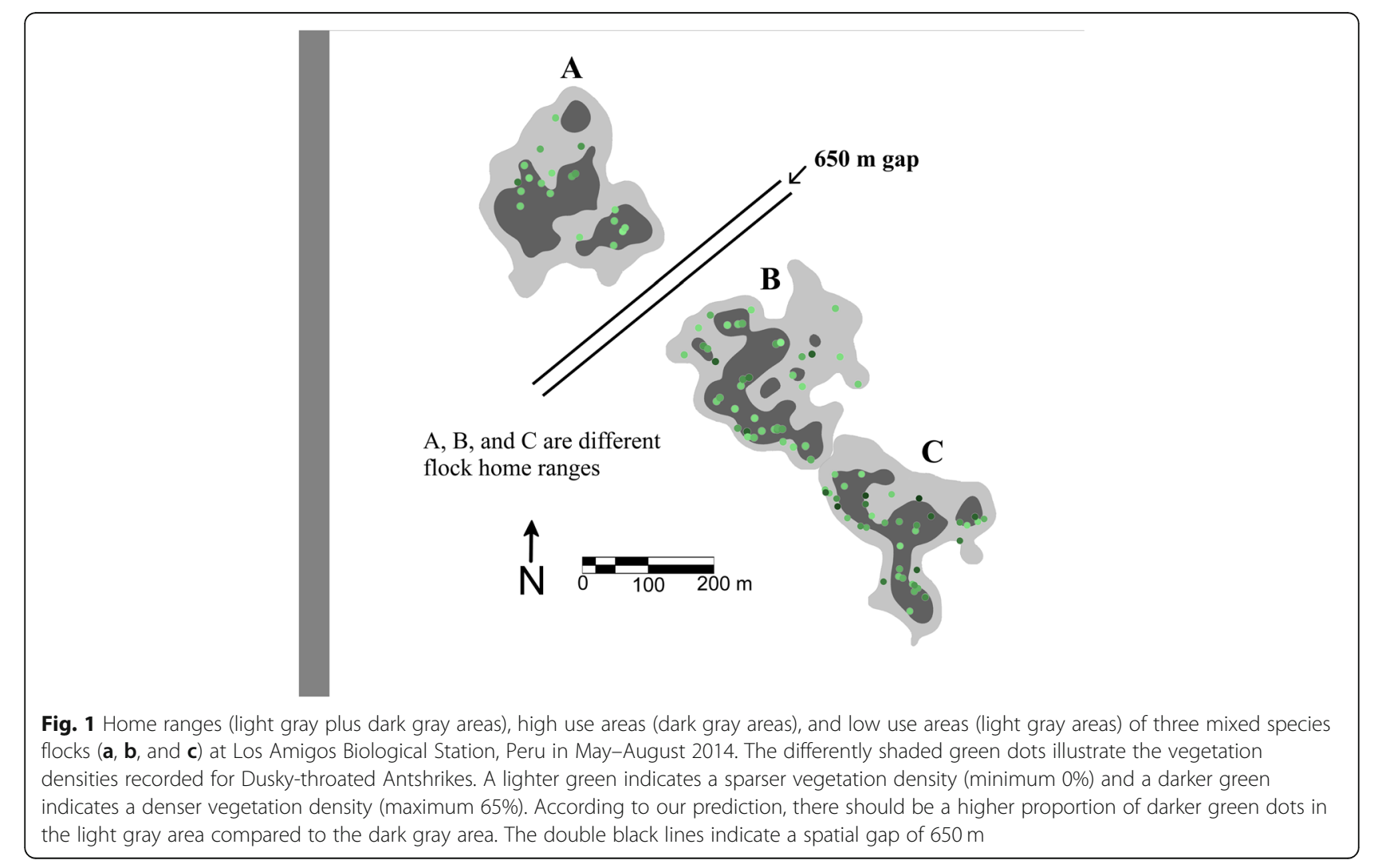


Table 1 Behavioral observations from the four most common species found in three understory flocks at Los Amigos Biological Station, Madre de Dios, Peru in 2014

\begin{tabular}{lllll}
\hline Species & $\begin{array}{l}\text { Number of } \\
\text { individuals }\end{array}$ & $\begin{array}{l}\text { Total number } \\
\text { of observations }\end{array}$ & $\begin{array}{l}\text { \% points in } \\
\text { high use } \\
\text { areas }\end{array}$ & $\begin{array}{l}\text { \% points in } \\
\text { low use } \\
\text { areas }\end{array}$ \\
\hline $\begin{array}{l}\text { Dusky-throated } \\
\text { Antshrike }\end{array}$ & 7 & 104 & 65 & 35 \\
$\begin{array}{l}\text { Bluish-slate } \\
\text { Antshrike }\end{array}$ & 4 & 38 & 34 & 66 \\
$\begin{array}{l}\text { Long-winged } \\
\text { Antwren }\end{array}$ & 9 & 139 & 63 & 37 \\
$\begin{array}{l}\text { White-flanked } \\
\text { Antwren }\end{array}$ & 6 & 48 & 50 & 50 \\
\hline
\end{tabular}

throated Antshrikes give loud alarm calls upon the detection of the forest-falcons. Their alarm call is a likely mechanism for the strong attraction of antwrens and transiently flocking species to Dusky-throated Antshrikes. The attraction of Dusky-throated Antshrikes to Longwinged Antwrens is relatively weak, although the reciprocal attraction is strong $[46,83]$. The nearly identical space use patterns of Dusky-throated Antshrikes and Longwinged Antwrens likely is due to this strong attraction (Table 1). Dusky-throated Antshrikes likely move to, and spend time in, areas with low vegetation density since, from the perspective of the Dusky-throated Antshrike, there are accessible prey and low predation risk. Other species then follow the Dusky-throated Antshrikes to gain anti-predation benefits [46]. Therefore, the space use patterns of Dusky-throated Antshrikes drive, at least in part, the space use patterns of the whole flock.

Table 2 Results of model selection for the ten models with the smallest $\triangle$ AIC plus a null model

\begin{tabular}{llll}
\hline Model & $\Delta$ AIC & $k$ & $w$ \\
\hline veg. DTAN & 0 & 4 & 0.53 \\
veg. DTAN + at. DTAN & 2.0 & 5 & 0.20 \\
veg. DTAN + vig. DTAN & 2.0 & 5 & 0.20 \\
veg. DTAN + at. DTAN + vig. DTAN & 4.0 & 6 & 0.073 \\
vig. DTAN & 10.9 & 4 & 0.0023 \\
at. DTAN & 11.2 & 4 & 0.0020 \\
at. DTAN + vig. DTAN & 12.8 & 5 & 0.00 \\
at. BSAN + at. WFAN + at. LWAN & 180.0 & 6 & 0.00 \\
veg. BSAN + veg. WFAN + veg. LWAN & 180.3 & 6 & 0.00 \\
vig. BSAN + vig. WFAN + vig. LWAN & 180.8 & 6 & 0.00 \\
& 380.3 & 3 & 0.00
\end{tabular}

The models relate behavioral variables of individual flock members to the space use of the entire flock. "veg" is the vegetation density, "at" is the attack rate, and "vig" is the vigilance rate. DTAN stands for Dusky-throated Antshrike, BSAN stands for Bluish-slate Antshrike, WFAN stands for White-flanked Antwren, and LWAN stands for Long-winged Antwren. We define $\triangle \mathrm{AIC}$ as the minimum AIC subtracted from the AIC of the corresponding model; $K$ is the number of included parameters; and $w$ is the normalized model likelihood [11]
Table 3 Means and standard deviations for the three variables of all four species included in the model

\begin{tabular}{|c|c|c|c|}
\hline Variable & Species & $\begin{array}{l}\text { High use } \\
\text { mean } \pm \text { SD }\end{array}$ & $\begin{array}{l}\text { Low use } \\
\text { mean } \pm \text { SD }\end{array}$ \\
\hline \multirow[t]{4}{*}{$\begin{array}{l}\text { Vegetation } \\
\text { density }\end{array}$} & $\begin{array}{l}\text { Dusky-throated } \\
\text { Antshrike }\end{array}$ & $0.140 \pm 0.102$ & $0.249 \pm 0.188$ \\
\hline & $\begin{array}{l}\text { Bluish-slate } \\
\text { Antshrike }\end{array}$ & $0.201 \pm 0.200$ & $0.132 \pm 0.101$ \\
\hline & $\begin{array}{l}\text { Long-winged } \\
\text { Antwren }\end{array}$ & $0.482 \pm 0.193$ & $0.505 \pm 0.190$ \\
\hline & $\begin{array}{l}\text { White-flanked } \\
\text { Antwren }\end{array}$ & $0.421 \pm 0.2085$ & $0.423 \pm 0.201$ \\
\hline \multirow[t]{4}{*}{ Attack rate } & $\begin{array}{l}\text { Dusky-throated } \\
\text { Antshrike }\end{array}$ & $0.0131 \pm 0.0149$ & $0.0128 \pm 0.00949$ \\
\hline & $\begin{array}{l}\text { Bluish-slate } \\
\text { Antshrike }\end{array}$ & $0.0230 \pm 0.0271$ & $0.0151 \pm 0.0136$ \\
\hline & $\begin{array}{l}\text { Long-winged } \\
\text { Antwren }\end{array}$ & $0.0285 \pm 0.0184$ & $0.0282 \pm 0.0226$ \\
\hline & $\begin{array}{l}\text { White-flanked } \\
\text { Antwren }\end{array}$ & $0.0196 \pm 0.0180$ & $0.0241 \pm 0.0191$ \\
\hline \multirow[t]{4}{*}{ Vigilance rate } & $\begin{array}{l}\text { Dusky-throated } \\
\text { Antshrike }\end{array}$ & $0.937 \pm 0.0294$ & $0.935 \pm 0.03040$ \\
\hline & $\begin{array}{l}\text { Bluish-slate } \\
\text { Antshrike }\end{array}$ & $0.946 \pm 0.0449$ & $0.963 \pm 0.0258$ \\
\hline & $\begin{array}{l}\text { Long-winged } \\
\text { Antwren }\end{array}$ & $0.0485 \pm 0.117$ & $0.0356 \pm 0.0756$ \\
\hline & $\begin{array}{l}\text { White-flanked } \\
\text { Antwren }\end{array}$ & $0.0394 \pm 0.0835$ & $0.0192 \pm 0.0488$ \\
\hline
\end{tabular}

The Dusky-throated Antshrike had a lower mean vegetation density in the high use areas of the flocks relative to the low use areas

We predicted that Dusky-throated Antshrikes would prefer to forage in areas with high foraging efficiency and low predation risk. The models containing attack rate and vigilance rate of the Dusky-throated Antshrike yielded the next best levels of support. Attack rate and vigilance rate may both be correlated with vegetation density, if Duskythroated Antshrikes select areas with the preferred vegetation density. However, using Pearson's product-moment correlation test, there was no significant positive or negative association between vegetation density and either attack rate or vigilance rate.

Although predation risk and resource availability frequently are associated with space use patterns, other mechanisms, such as competition, may play a role in space use. Neotropical insectivorous birds, i.e. antbirds, defend territories against floater individuals or territory intruders $[22,50]$. Because antbirds are highly territorial, it is possible that Dusky-throated Antshrikes spend time in areas with sparse vegetation in order to visually search for and chase away territory intruders [77]. If this hypothesis is correct, the simulated presence of intruding conspecifics (e.g. through playback) should cause Dusky-throated Antshrikes to forage in sparsely vegetated areas more frequently than control Dusky-throated Antshrikes. 
Alternatively, we recognize that the behavioral variables we measured-attack rate and vigilance rate-are proxies for available food resources and predation risk, and therefore are imperfect measures of real-time food resource availability and predation risk $[37,63]$. It is possible that the actual success rate of capturing prey items and the actual predation risk were higher and lower, respectively, in the low vegetation areas compared to the high-vegetation areas, but that our measures could not capture these differences.

Another species of antshrike, the Bluish-slate Antshrike, has been considered to perform a similar role to the Dusky-throated Antshrike in mixed-species flocks; they give raucous alarm calls in the presence of predators and are thought to be leaders of some flocks [38, 52, 53]. Bluishslate Antshrikes occurred in two flocks intermittently. On several occasions ( $n \sim 20)$, the Bluish-slate Antshrike departed from the flock and continued foraging in other parts of the home range. Whenever the Bluish-slate Antshrike departed from the flock, the White-flanked Antwrens also disappeared and on the three occasions we pursued the Bluish-slate Antshrikes, we found the White-flanked Antwrens and Bluish-slate Antshrikes associated with each other. It is possible that the Bluish-slate Antshrike plays a role similar to the role of the Dusky-throated Antshrike and influences flock space use disproportionately for other flock species.

\section{Conclusion}

The vegetation density surrounding the Dusky-throated Antshrikes was the best predictor of high and low use of the home range of the flock. Other species around the world may dictate space use patterns of mixed-species flocks similar to the Dusky-throated Antshrikes. Such species include Orange-billed Babblers (Turdoides rufescens) and Greater Racket-tailed Drongos (Dicrurus paradiseus) in Sri Lanka, Square-tailed Drongos (Dicrurus ludwigii) in Tanzania, Buff-rumped Thornbills (Acanthiza reguloides) in Australia, and Gray-cheeked Fulvettas (Alcippe morrisonia) in Taiwan $[15,16,21,40]$. Drongos visually scan for insects in sparsely vegetated areas, similar to the Duskythroated Antshrike, and so flocks led by drongos may spend a disproportionate amount of time in sparsely vegetated areas relative to the available vegetation densities [28, 64]. Some species may serve only as indicators of a flock's presence and not confer foraging or anti-predation benefits to flocking species, e.g. the Orange-billed Babbler [28]. These indicator species may not drive space use patterns of the flock since transient species, after having found the flock, would experience no benefit from following the indicator species after they have joined the flock. Future studies should aim to predict habitat variables that are important to beneficial species, and investigate whether the space use patterns of the flock are associated with those habitat variables across the flock's home range.

\section{Appendix}

Table 4 The surrounding vegetation densities (veg), attack rates (at), and vigilance rates (vig) of Dusky-throated Antshrikes (DTAN), Bluish-slate Antshrikes (BSAN), White-flanked Antwrens (WFAN), and Long-winged Antwrens (LWAN) were included in a full model. Reduced models included different combinations of the four focal species and three behavioral data types based on different predictions of the four species and behavioral variables

Models included in analyses

DTAN (at+vig + veg) + BSAN (at+vig + veg) + LWAN (at+vig + veg) + WFAN (at+vig + veg)

DTAN (at+vig) + BSAN (at+vig) + LWAN (at+vig) + WFAN (at+vig)

DTAN (at+veg) + BSAN (at+veg) + LWAN (at+veg) + WFAN (at+vig)

DTAN (vig + veg) + BSAN (vig + veg) + LWAN (vig + veg) + WFAN (vig + veg)

DTANat+BSANat+LWANat+WFANat

DTANvig+BSANvig+LWANvig+WFANvig

DTANveg+BSANveg+LWANveg+WFANveg

At+vig + veg

At+vig

At+veg

Vig + veg

At

Vig

Veg

DTAN (at+vig + veg)

DTAN (at+vig)

DTAN (at+veg)

DTAN (vig + veg)

DTANat

DTANvig

DTANveg

BSAN (at+vig + veg) + LWAN (at+vig + veg) + WFAN (at+vig + veg)

BSAN (at+vig) + LWAN (at+vig) + WFAN (at+vig)

BSAN (at+veg) + LWAN (at+veg) + WFAN (at+vig)

BSAN (vig + veg) + LWAN (vig + veg) + WFAN (vig + veg)

BSANat+LWANat+WFANat

BSANvig+LWANvig+WFANvig

BSANveg+LWANveg+WFANveg 
Table 5 List of participating species found in mixed-species flocks at Los Amigos Biological Station May-Aug 2014. Nuclear species are always or nearly always found in all or nearly all flocks. Common transients are found in at least some flocks at least some of the time, and uncommon transients are found in few flocks some of the time

\begin{tabular}{|c|c|c|}
\hline Nuclear & $\begin{array}{l}\text { Common transient/ } \\
\text { semi-nuclear }\end{array}$ & Uncommon transient \\
\hline $\begin{array}{l}\text { Dusky-throated } \\
\text { Antshrike } \\
\text { (Thamnomanes } \\
\text { ardesiacus) }\end{array}$ & $\begin{array}{l}\text { Bluish-slate } \\
\text { Antshrike } \\
\text { (Thamnomanes } \\
\text { schistogynus) }\end{array}$ & $\begin{array}{l}\text { Fasciated Antshrike } \\
\text { (Cymbilaimus lineatus) }\end{array}$ \\
\hline \multirow[t]{18}{*}{$\begin{array}{l}\text { Long-winged } \\
\text { Antwren } \\
\text { (Myrmotherula } \\
\text { longipennis) }\end{array}$} & $\begin{array}{l}\text { White-eyed } \\
\text { Antwren } \\
\text { (Epinecrophylla } \\
\text { leucophthalma) }\end{array}$ & $\begin{array}{l}\text { Plain-throated Antwren } \\
\text { (Isleria hauxwelli) }\end{array}$ \\
\hline & $\begin{array}{l}\text { Madeira Antwren } \\
\text { (Epinecrophylla } \\
\text { amazonica) }\end{array}$ & $\begin{array}{l}\text { Spot-winged Antshrike } \\
\text { (Pygiptila stellaris) }\end{array}$ \\
\hline & $\begin{array}{l}\text { White-flanked Antwren } \\
\text { (Myrmotherula axillaris) }\end{array}$ & $\begin{array}{l}\text { Ornate Antwren } \\
\text { (Epinecrophylla ornata) }\end{array}$ \\
\hline & $\begin{array}{l}\text { Gray Antwren } \\
\text { (Myrmotherula } \\
\text { menetriesii) }\end{array}$ & $\begin{array}{l}\text { Sclater's Antwren } \\
\text { (Myrmotherula sclateri) }\end{array}$ \\
\hline & $\begin{array}{l}\text { Elegant Woodcreeper } \\
\text { (Xiphorhynchus elegans) }\end{array}$ & $\begin{array}{l}\text { Pygmy Antwren } \\
\text { (Myrmotherula brachyura) }\end{array}$ \\
\hline & $\begin{array}{l}\text { Buff-throated } \\
\text { Woodcreeper } \\
\text { (Xiphorhynchus guttatus) }\end{array}$ & $\begin{array}{l}\text { Cinnamon-rumped Foliage- } \\
\text { gleaner } \\
\text { (Philydor pyrrhodes) }\end{array}$ \\
\hline & $\begin{array}{l}\text { Rufous-rumped Foliage- } \\
\text { gleaner } \\
\text { (Philydor erythrocercum) }\end{array}$ & $\begin{array}{l}\text { Rufous-tailed Foliage- } \\
\text { gleaner } \\
\text { (Anabacerthia ruficaudata) }\end{array}$ \\
\hline & $\begin{array}{l}\text { Olive-backed Foliage- } \\
\text { gleaner } \\
\text { (Automolus infuscatus) }\end{array}$ & $\begin{array}{l}\text { Amazonian Barred- } \\
\text { Woodcreeper } \\
\text { (Dendrocolaptes certhia) }\end{array}$ \\
\hline & $\begin{array}{l}\text { Tawny-crowned Greenlet } \\
\text { (Tunchiornis ochraceiceps) }\end{array}$ & $\begin{array}{l}\text { Black-tailed Leaftosser } \\
\text { (Sclerurus caudatus) }\end{array}$ \\
\hline & $\begin{array}{l}\text { Red-crowned Ant- } \\
\text { Tanager } \\
\text { (Habia rubica) }\end{array}$ & $\begin{array}{l}\text { Olivaceous Woodcreeper } \\
\text { (Sittasomus griseicapillus) }\end{array}$ \\
\hline & & $\begin{array}{l}\text { Long-tailed Woodcreeper } \\
\text { (Deconychura longicauda) }\end{array}$ \\
\hline & & $\begin{array}{l}\text { Plain-brown Woodcreeper } \\
\text { (Dendrocincla fuliginosa) }\end{array}$ \\
\hline & & $\begin{array}{l}\text { Ocellated Woodcreeper } \\
\text { (Xiphorhynchus ocellatus) }\end{array}$ \\
\hline & & $\begin{array}{l}\text { Plain Xenops } \\
\text { (Xenops minutus) }\end{array}$ \\
\hline & & $\begin{array}{l}\text { Olive-striped Flyatcher } \\
\text { (Mionectes olivaceus) }\end{array}$ \\
\hline & & $\begin{array}{l}\text { Ochre-bellied Flycatcher } \\
\text { (Mionectes oleagineus) }\end{array}$ \\
\hline & & $\begin{array}{l}\text { Ruddy-tailed Flycatcher } \\
\text { (Terenotriccus erythrurus) }\end{array}$ \\
\hline & & $\begin{array}{l}\text { Musician Wren } \\
\text { (Cyphorhinus arada) }\end{array}$ \\
\hline
\end{tabular}

\section{Abbreviations}

BSAN: Bluish-slate Antshrike; DTAN: Dusky-throated Antshrike; LWAN: Longwinged Antwren; WFAN: White-flanked Antwren

\section{Acknowledgments}

Staff of the Asociación para la Conservación de la Cuenca Amazónica were essential in providing a comfortable place to live during the study. F. A. Pratolongo assisted in submitting permits.

\section{Authors' contributions}

SW and $\mathrm{CL}$ designed the methods and interpreted the results. SW collected and analyzed the data. SW and CL wrote the manuscript and approve the final version.

\section{Funding}

The National Science Foundation provided critical support during the early stages of this study. The Integrative Biology (formerly Zoology) Department, Center for Latin American and Caribbean Studies, the Graduate School, and the Ecology, Evolutionary, Biology and Behavior Program at Michigan State University provided additional support.

\section{Availability of data and materials}

The data are available online with the supplementary materials of this publication

\section{Ethics approval and consent to participate}

The methods in this paper were in compliance with, and have been approved by, the Institutional Animal Care and Use Committee, AUF \# 06/ 13-137-00.

\section{Consent for publication}

Not applicable.

\section{Competing interests}

The authors declare that they have no competing interests.

\section{Author details}

${ }^{1}$ Department of Integrative Biology, Michigan State University, East Lansing, MI, USA. ${ }^{2}$ Program for Ecology, Evolutionary Biology, and Behavior, Michigan State University, East Lansing, MI, USA. ${ }^{3}$ Department of Biology, College of the Holy Cross, Worcester, MA, USA. ${ }^{4}$ Center for Global Change and Earth Observations, Michigan State University, East Lansing, MI, USA.

Received: 18 July 2019 Accepted: 15 October 2019

Published online: 28 November 2019

\section{References}

1. Altmann J. Observational study of behavior: sampling methods. Behav. 1974;49:227-67.

2. Anich NM, Benson TJ, Bednarz JC. Estimating territory and home-range sizes: do singing locations alone provide an accurate estimate of space use? Auk. 2009;126:626-34

3. Anich NM, Benson TJ, Bednarz JC. What factors explain differential space use within Swainson's warbler (Limnothlypis swainsonii) home ranges? Auk. 2012;129:409-18.

4. Arbelaez-Cortes $\mathrm{E}$, Marin Gomez OH. The composition of mixed-species bird flocks in alto Quindio, Colombia. Wilson J of Ornith. 2012;124:572-80.

5. Bates D, Maechler M, Bolker B, Walker S. Fitting linear mixed-effects models using Ime4. J of Stat Software. 2015;67:1-48.

6. Battin J. When good animals love bad habitats: ecological traps and the conservation of animal populations. Conserv Biol. 2004;18:1482-91.

7. Bodie JR, Semlitsch RD. Spatial and temporal use of floodplain habitats by lentic and lotic species of aquatic turtle. Oecologia. 2000;122:138-46.

8. Bohorquez $\mathrm{Cl}$. Mixed-species bird flocks in a montane cloud forest of Colombia. Ornitología Neotropical. 2003;14:67-78.

9. Bolker B, R Core Team. bbmle: Tools for General Maximum Likelihood Estimation. 2016. R package version 1.0.18.

10. Bruggeman JE, Swem T, Andersen DE, Kennedy PL, Nigro D. Multi-season occupancy models identify biotic and abiotic factors influencing a recovering Arctic Peregrine falcon Falco peregrinus tundrius population. Ibis. 2016;158:61-74 
11. Burnham KP, Anderson DR. Model selection and multi-mode inference. Springer Press: 2002.

12. Calenge $C$. The package adehabitat for the $R$ software: a tool for the analysis of space and habitat use by animals. Ecol Model. 2006;197:516-9.

13. Caraco T, Martindale S, Pulliam HR. Avian flocking in presence of a predator. Nature. 1980:285:400-1.

14. Caras T, Korine C. Effect of vegetation density on the use of trails by bats in secondary tropical rain forest. J of Trop Ecol. 2009;25:97-101.

15. Chen C, Hsieh F. Composition and foraging behavior of mixed-species flocks led by the gray-cheeked Fulvetta in Fushan experimental Forest. Taiwan Ibis. 2002;144:317-30

16. Cordeiro NJ, Borghesio L, Joho MP, Monoski TJ, Mkongewa VJ, Dampf CJ. Forest fragmentation in an African biodiversity hotspot impacts mixedspecies bird flocks. Biol Conserv. 2015;188:61-71.

17. Darrah A, Smith K. Comparison of foraging behaviors and movements patterns of the wedge-billed Woodcreeper (Glyphorynchus spirurus) traveling alone and in mixed-species flocks in Amazonian Ecuador. Auk. 2013;130:629-36.

18. Dugger KM, Anthony RG, Andrews LS. Transient dynamics of invasive competition: barred owls, spotted owls, habitat, and the demons of competition present. Ecol Appl. 2011;21:2459-68.

19. Dupuch A, Dill LM, Magnan P. Testing the effects of resource distribution and inherent habitat riskiness on simultaneous habitat selection by predators and prey. Animal Behav. 2009;78:705-13.

20. Effenberger $E$, Mouton PLN. Space use in a multi-male group of the groupliving lizard. J of Zool. 2007;272:202-8.

21. Farine DR, Milburn PJ. Social organisation of thornbill-dominated mixedspecies flocks using social network analysis. Behav Ecol and Sociobiol. 2013; 67:321-30

22. Fedy BC, Stutchbury BJM. Territory switching and floating in white-bellied Antbird (Myrmeciza longipes), a resident tropical passerine in Panama. Auk. 2004;121:486-96.

23. Fraker ME, Luttbeg B. Predator-prey space use and the spatial distribution of predation events. Behav. 2012;149:555-74.

24. Frei B, Fyles JW, Nocera JJ. Maladaptive habitat use of a north American woodpecker in population decline. Ethol. 2013;119:377-88.

25. Garcia-Charton JA, Perez-Ruzafa A. Spatial pattern and the habitat structure of a Mediterranean rocky reef local assemblage. Mar Biol. 2001;138:917-34

26. Goodale E, Beauchamp G, Ruxton D. Mixed-species groups of animals: behavior, community structure, and conservation. London: Academic Press; 2017

27. Goodale E, Ding P, Liu X, Martinez A, Si X, Walters M, Robinson SK. The structure of mixed-species bird flocks and their response to anthropogenic disturbance, with special reference to East Asia. Avian Res. 2015;6:14.

28. Goodale E, Kotagama SW. Testing the roles of mixed-species bird flocks of a Sri Lankan rain forest. J of Trop Ecol. 2005;21:669-76.

29. Gordon Al, Harrison NM. Observations of mixed-species bird flocks at Kichwa Tembo camp, Kenya. Ostrich. 2010;81:259-64

30. Greenberg R. Birds of many feathers: the formation and structure of mixedspecies flocks of forest birds. In: Boinski S, Garber PA, editors. On the move: how and why animals travel in groups. Chicago: University of Chicago Press; 2000. p. 521-58

31. Haffner CD, Cuthbert FJ, Arnold TW. Space use by Great Lakes piping plovers during the breeding season. J of Field Ornith. 2009;80:270-9.

32. Hammerschlag N, Heithaus MR, Serafy JE. Influence of predation risk and food supply on nocturnal fish foraging distributions along a mangroveseagrass ecotone. Marine Ecol Progress Series. 2010;414:223-35.

33. Heithaus MR, Wirsing AJ, Burkholder D, Thomson J, Dill LM. Towards a predictive framework for predator risk effects: the interaction of landscape features and prey escape tactics. J of Animal Ecol. 2009;78:556-62.

34. Heupel MR, Simpfendorfer CA, Hueter RE. Estimation of shark home ranges using passive monitoring techniques. Enviro Biol of Fishes. 2004;71:135-42.

35. Hogstad O. Winter flock coherence in willow tits- who decide what and why? Ornis Norvegica. 2009;32:190-201.

36. Holmes RT, Schultz JC. Food availability for forest birds: effects of prey distribution and abundance on bird foraging. Canad J of Zool. 1988:66:720-8.

37. Hutto RL. Measuring the availability of food resources. In: Morrison ML, Ralph CJ, Verner J, Jehl JR Jr., editors. Avian foraging: theory, methodology, and applications. Studies of Avian Biol 13. 1990. p. 20-8.

38. Jullien M, Thiollay JM. Multi-species territoriality and dynamics of Neotropical forest understory bird flocks. J of Animal Ecol. 1998;67:227-52.
39. Kearney M, Porter W. Mechanistic niche modeling: combining physiological and spatial data to predict species' ranges. Ecol Lett. 2009;12:334-50.

40. Kotagama SW, Goodale E. The composition and spatial organisation of mixed-species flocks in a Sri Lankan rainforest. Forktail. 2004;20:63-70.

41. Krebs J, Lofroth EC, Parfitt I. Multiscale habitat use by wolverines in British Colombia. Canada J of Wildl Manag. 2007;71:2180-92.

42. Lair $\mathrm{H}$. Estimating the location of the focal center in red squirrel home ranges. Ecol. 1987;68:1092-101.

43. Lima SL, Dill LM. Behavioral decisions made under the risk of predation: a review and prospectus. Canad J of Zool. 1990;68:619-40.

44. Maldonado-Coelho M, Marini MA. Mixed-species bird flocks from the Brazilian Atlantic forest: the effects of forest fragmentation and seasonality on their size, richness and stability. Biol Conserv. 2004:116:19-26.

45. Martinez AE, Gomez JP. Are mixed-species bird flocks stable through two decades? Am Nat. 2013:181:E53-9.

46. Martinez AE, Zenil RT. Foraging guild influences dependence on heterospecific alarm calls in Amazonian birds flocks. Behav Ecol. 2012;23: 544-50.

47. Monús F, Barta Z. Is foraging time limited during winter? - a feeding experiment with tree sparrows under different predation risk. Ethol. 2016; 122:20-9.

48. Morrison EB, Lindell CA. Active or passive forest restoration? Assessing restoration alternatives with avian foraging behavior. Restor Ecol. 2011;19: 170-7.

49. Morse DH. Ecological aspects of some mixed-species flocks of birds. Ecol Monogr. 1970;40:119-68

50. Morton ES, Derrickson KC, Stutchbury BJM. Territory switching in a sedentary tropical passerine, the dusky Antbird (Cercomacra tyrannina). Behav Ecol. 2000;11:648-53.

51. Moynihan M. The organization and probably evolution of some mixed species flocks of Neotropical birds. Smithsonian Miscellaneous Collection. 1962;143:1-140.

52. Munn C. Permanent canopy and understory flocks in Amazonia: species composition and population density. Ornith Monographs. 1985;36.

53. Munn C, Terborgh J. 1979. Multi-species territoriality in neotropical foraging flocks. Condor. 1979:81:338-47.

54. Nathan R, Getz WM, Revilla E, Holyoak M, Kadmon R, Saltz D, Smouse PE. A movement ecology paradigm for unifying organismal movement research. Proc Natl Acad Sci. 2008;105:19052-9.

55. Nininuan S, Round PD, Gale GA. Structure and composition of mixedspecies bird flocks in Khao Yai National Park. Nat Hist Bull of the Siam Soc. 2004;52:71-9.

56. Orians GH, Wittenberger JF. Spatial and temporal scales in habitat selection. Am Nat. 1991;137:S29-9

57. Pechacek P. Foraging behavior of Eurasian three-toed woodpeckers (Picoides tridactylus alpinus) in relation to sex and season in Germany. Auk. 2006:123:235-46.

58. Plissner JH, Oring LW, Haig SM. Space use of killdeer at a Great Basin breeding area. J of Wildl Manag. 2000;64:421-9.

59. Pomara LY, Cooper RJ, Petit LS. Mixed-species flocking and foraging behavior of four Neotropical warblers in Panamanian shade coffee fields and forests. Auk. 2003;120:1000-12.

60. Potts JR, Mokross K, Stouffer PC, Lewis MA. Step selection techniques uncover the environmental predictors of space use patterns in flock of Amazonian birds. Ecol and Evol. 2014:4:4578-88.

61. R Core Team. R: A language and environment for statistical computing. $R$ Foundation for Statistical Computing. 2005. https://www.R-project.org/.

62. Remsen JV, Robinson SK. A classification scheme for foraging behavior of birds in terrestrial habitats. In: Morrison M, Ralph CJ, Vemer J, Jehl J, editors. Avian foraging: theory, methodology, and applications. 1990. Studies of Avian Biol 13. p. 144-60.

63. Robinson SK, Holmes RT. Effects of plant-species and foliage structure on the foraging behavior of forest birds. Auk. 1984;101:672-84

64. Rocamora GJ, Yeatman-Berthelot D. 2009. Family Dicruridae (drongos). In: del Hoyo J, Elliot a, Christie DA, editors. Handbook of the birds of the world. Volume 14. Bush-shrikes to Old World sparrows. Barcelona: Lynx Edicions. p. $172-226$.

65. Rosenberg KV. Diet selection in Amazonian antwrens: consequences of substrate specialization. Auk. 1993;110:361-75.

66. Samuel MD, Pierce DJ, Garten EO. Identifying areas of concentrated use within the home range. J of Animal Ecol. 1985;54:711-9. 
67. Scheinin M, Scyphers S, Kuappi L, Heck KL, Mattila K. The relationship between vegetation density and its protective value depends on the densities and traits of prey and predators. Oikos. 2012;121:1093-102.

68. Schlaepfer MA, Runge MC, Sherman PW. Ecological and evolutionary traps. Trends in Ecol and Evol. 2002;17:474-80.

69. Schulenberg T. Foraging behavior, eco-morphology, and systematics of some antshrikes (Formicariidae: Thamnomanes). Wilson Bull. 1983;95:505-21.

70. Seaman DE, Millspaugh JJ, Kernohan BJ, Brundige GC, Raedeke KJ, Gitzen RA. Effects of sample size on kernel home range estimates. J Wildl Manag. 1999;63:739-47.

71. Signer J, Balkenhol N. Reproducible home ranges (rhr): a new, user-friendly R package for wildlife telemetry data. Wildl Soc Bull. 2015;39:358-63.

72. Sridhar H, Beauchamp G, Shanker K. Why do birds participate in mixed-species foraging flocks? A large-scale synthesis. Animal Behav. 2009;78:337-47.

73. Sridhar H, Srinivasan U, Askins RA, Canales-Delgadillo JC, Chen CC, Ewert DN, Gale GA, Goodale E, Gram WK, Hart PJ, Hobson KA, Hutto RL, Kotagama SW, Knowlton JL, Lee TM, Nizam BZ, Peron G, Robin W, Rodewald AD, Rodewald PG, Thomson RL, Trivedi P, VanWilgenburg SL, Shanker K. Positive relationships between association strength and phenotypic similarity characterize the assembly of mixed-species bird flocks worldwide. Am Nat. 2012;180:777-90

74. Srinivasan U, Raza RH, Quader S. The nuclear question: rethinking species importance in multi-species animal groups. J of Animal Ecol. 2010;79:948-54.

75. Stotz DF. Geographic variation in species composition of mixed species flocks in lowland humid forests in Brazil. Papeis Avulsos de Zool. 1993;38:61-75.

76. Strandburg-Peshkin A, Farine DR, Couzin ID, Crofoot MC. Shared decisionmaking drives collective movement in wild baboons. Science. 2015;348: 1358-61.

77. Stutchbury BJM, Morton ES. Behavioral ecology of tropical birds. San Diego: Academic; 2001

78. Swihart RK, Slade NA. Testing for independence of observations in animal movements. Ecol. 1985;66:1176-84.

79. Terborgh J. Mixed flocks and polyspecific associations: costs and benefits of mixed groups to birds and monkeys. Am J of Primatol. 1990;21:87-100.

80. Thiollay JM. Comparative foraging behavior between solitary and flocking insectivores in a Neotropical forest: does vulnerability matter? Ornitologia Neotropical. 2003;14:47-65.

81. Tolon V, Dray S, Loison A, Zeileis A, Fischer C, Baubat E. Responding to spatial and temporal variations in predation risk: space use of a game species in a changing landscape of fear. Canad J of Zool. 2009;87:1129-37.

82. Vanderduys EP, Kutt AS, Perry JJ, Perkins GC. 2012. The composition of mixed-species bird flocks in northern Australian savannas. Emu. 2012;112: 218-26.

83. Williams SM, Lindell CA. Nuclear species in Peruvian mixed-species flocks are differentially attractive to transient species and to each other. Wilson J of Ornith. 2018;130:131-9.

84. Worton BJ. Kernel methods for estimating the utilization distribution in home-range studies. Ecol. 1989;70:164-8.

\section{Publisher's Note}

Springer Nature remains neutral with regard to jurisdictional claims in published maps and institutional affiliations.

\section{Ready to submit your research? Choose BMC and benefit from:}

- fast, convenient online submission

- thorough peer review by experienced researchers in your field

- rapid publication on acceptance

- support for research data, including large and complex data types

- gold Open Access which fosters wider collaboration and increased citations

- maximum visibility for your research: over $100 \mathrm{M}$ website views per year

At $\mathrm{BMC}$, research is always in progress.

Learn more biomedcentral.com/submissions 